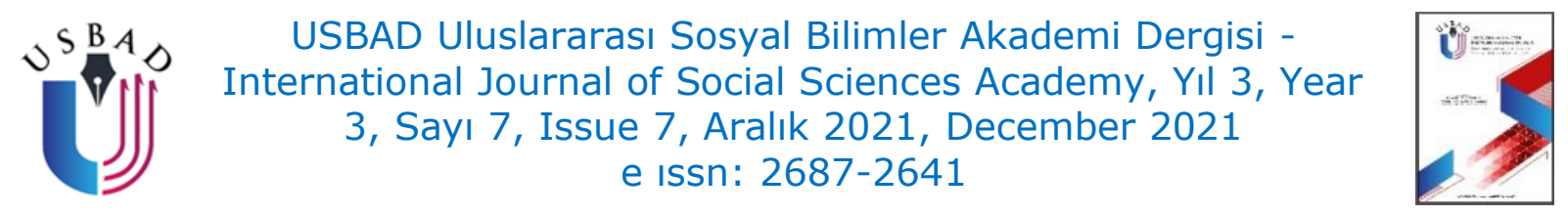

\title{
MEDİKAL TURİSTLERİN TIBBİ TEDAVİ TERCİHLERİ: ANTALYA İLİ ÖRNEĞİ
}

MEDICAL TREATMENT PREFERENCES OF MEDICAL TOURISTS: ANTALYA CASE

\author{
Gamze ALP \\ Araştırma Görevlisi, Bitlis Eren Üniversitesi, Kanık Uygulamalı Bilimler \\ Yüksekokulu, \\ Bitlis/Türkiye. \\ Research Assistant, Bitlis Eren University, Kanık School of Applied \\ Sciences, Bitlis/Turkey. \\ gamzeyilmazalp@hotmail.com \\ ORCID ID: 0000-0002-6925-280X \\ Makale bilgisi | Article Information \\ DOI: $10.47994 /$ usbad.953262 \\ Makale Türü / Article Type: Araştırma Makalesi / Research Article \\ Geliş Tarihi / Date Received: 16.06.2021 \\ Kabul Tarihi / Date Accepted: 01.10.2021 \\ Yayın Tarihi / Date Published: 20.12.2021 \\ Yayın Sezonu / Pub Date Season: Aralık / December
}

Bu Makaleye Atıf İçin / To Cite This Article: Alp, G. (2021). Medikal Turistlerin Tıbbi Tedavi Tercihleri: Antalya İli Örneği. USBAD Uluslararası Sosyal Bilimler Akademi Dergisi 3(7), 1570-1586.

İntihal: Bu makale intihal.net yazılımınca taranmıştır. İntihal tespit edilmemiştir. Plagiarism: This article has been scanned by intihal.net. No plagiarism detected.

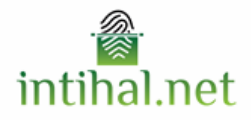

İletişim: Web: https://dergipark.org.tr/tr/pub/usbad mail: usbaddergi@gmail.com 
Öz: Çalışmanın temel amacı Antalya'da medikal tedavi hizmeti almış olan medikal turistlerin demografik profilini anlamak, Antalya'yı medikal tedavi için seçerken hangi kaynaklardan bilgi aldıklarını öğrenmek ve Antalya'da hangi medikal tedavilerden yararlandıklarını araştırmaktır. Bu amaçla Antalya'ya gelen medikal turistlerin yaş, cinsiyet, eğitim seviyesi, gelir düzeyi, Antalya ve Türkiye ziyareti sayıları, gelmeden önce yardım aldıkları bilgi kaynakları ve aldıkları tedavi çeşitleri gibi faktörler incelenmiştir. Bu kapsamda daha önce Antalya'da medikal tedavi hizmeti almış olan veya anketin yapıldığı dönemde medikal tedavi almak için gelmiş olan medikal turistler çalışmaya dahil edilmiştir. Medikal turistlere tedavi aldıkları medikal tesiste ya da konaklama tesisinde ulaşılmıştır. Çalışma Antalya merkezde yürütülmüştür. Çalışma sonunda ulaşılan medikal turist kitlesinin 34-50 yaş aralığında olduğu, eğitim seviyelerinin iyi olduğu, Alman uyrukluların çoğunlukta olduğu ve gelenlerin en çok diş tedavisinden yararlandığı gibi sonuçlara ulaşılmıştır. Araştırmadan elde edilen sonuçlar, Antalya'ya gelen medikal turistlerin daha iyi anlaşıımasını sağlayarak buna yönelik gelişimler yapılmasını sağlayacaktır.

Anahtar Sözcükler: Medikal, Medikal Turizm, Medikal Tedavi

Abstract: The main purpose of the study is to understand the demographic profile of medical tourists who have received medical treatment in Antalya, to learn from which sources they get information when choosing Antalya for medical treatment and which medical treatments they benefit from in Antalya. For this purpose, various factors related to Antalya medical tourist profile were investigated: age, gender, education, income, number of visits, information sources and types of treatment. In this context, medical tourists who received medical treatment in Antalya before or who came to receive medical treatment at the time of the survey were included in the study. Medical tourists were reached at the medical facility or accommodation facility where they received treatment. The study was carried out in the center of Antalya. At the end of the study, it was concluded that the medical tourist group reached was between the ages of 34-50, their education level was good, German nationals were in the majority, and those who came mostly benefited from dental treatment The results obtained from the research will provide a better understanding of the medical tourists coming to Antalya and make improvements in this regard.

Key Words: Medical, Medical Tourism, Medical Treatment

\section{GİRİŞ}

Medikal turizm, "diş bakımı, kozmetik prosedürler, cerrahi ve doğurganlık tedavileri gibi medikal tedavileri almak için uluslararası sınırların ötesine seyahat etmek" olarak tanımlanmaktadır (Kelley, 2013). Bireylerin kendi ülkelerinde var olana kıyasla daha kaliteli tıbbi, diş ve cerrahi hizmetlere ulaşabilmek adına başka bir ülkeye seyahat etmesi olarak da tanımlanmaktadır (Medical Tourism Association, 2014). Tanımlardan da anlaşılacağı üzere medikal turizm hem turizmle hem de sağlıkla bağlantılıdır. Turizm ve medikal tedavi alma arasındaki bu bağlantı, bilinen 
turizm faaliyetlerinin medikal turizm yoluyla (ulaşım sektörü, yiyecek ve içecek hizmetleri, konaklama sektörü $v b$.) önemli faydalar elde etmesine yardımcı olmuştur. Ek olarak Lunt, Smith, Mannion, Green, Exworthy, Hanefeld, Horsfall, Machin ve King (2014), turizm faaliyetinin medikal turistlerin karar verme sürecinde çevresel bir rol oynadığını, ancak son kararların öncelikle sağlık nedenleriyle alındığına işaret etmektedir.

Altın, Singal ve Kara (2011), medikal turistlerin birincil amacının intiyaç duyulan medikal tedaviyi alabilmek adına, düşük maliyetle en iyi destinasyonu seçmek olduğunu belirtmektedir. Akreditasyonlu hastanelerin, medikal tedavi sunan tesislerin ve tanınan medikal uzmanların varlığının, gidilecek medikal destinasyonun seçiminde dikkate alınan unsurlar olduğu belirtilmektedir. Gidilecek destinasyonun, ekonomik, politik, sosyo-kültürel, yasal ve teknolojik gelişmişlikleri de göz önünde bulundurulan diğer faktörlerdir. Yeni deneyimlere açıklık, gidilecek destinasyonun kültür ve diline olan aşinalık gibi kişisel faktörlerinde destinasyonla ilgili karar vermede destekleyici faktörler olduğu görülmektedir. Ayrıca, yaş, gelir düzeyi ve eğitim seviyesi gibi sosyodemografik özelliklerinde medikal hizmetler için belirli bir ülkeye yapılacak seyahat kararını etkilediği gösterilmiştir (Altın vd., 2011).

Medikal turistleri çekmek isteyen ülkeler arasında görülen bir rekabet bulunmaktadır. Geçmişte, gelişmekte olan ülkelerden varlıklı kişiler kaliteli tıbbi bakım almak için gelişmiş ülkelere seyahat etmekteydi. Ancak şu anda, gelişmiş ülkelerden bireyler gelişmekte olan ülkelere giderek medikal bakım almak için seyahat etmektedir. Bu da gelişmekte olan ülkeleri medikal turizm için popüler destinasyonlar haline getirmektedir (Hallem ve Barth, 2011; Veerasoontorn vd., 2011). Dünya genelinde tedavi maliyetlerinin düşüklüğü bu dönüşümün temel nedeni olarak görülmektedir (Hadi, 2009; Herrick, 2007). Türkiye'ye gelindiğinde ise bu dönüşümde fiyatın yanı sıra farklı avantajlar da etkili olmaktadır. Örneğin; akredite edilmiş sağlık tesislerinin fazlalığı, yüksek tıbbi teknolojileri, nitelikli insan gücü, elverişli iklimi, gelişmiş medikal cihazları, termal kaynakları, yabancı dil bilen personelleri ile Türkiye lider medikal turizm destinasyonları arasında yerini almıştır (Sağlık Bakanlığı, 2012). Bu nedenle de incelenmesi gereken bir ülke olarak düşünülmüştür. Ancak çalışmanın Türkiye çapında yapılması zaman ve maliyet açısından mümkün olmadığından sağlık turistlerinin Türkiye'deki en çok tercih ettikleri şehirler olan İstanbul ve Antalya (Antalya Homes, 2021) arasından Antalya ili tercih edilmiştir. Bu kapsamda Antalya iline gelen medikal turistler evren, Antalya merkezde ulaşılabilen medikal turistler ise örneklem olarak alınmıştır. Çalışma, Antalya'da medikal tedavi hizmeti almış olan medikal turistlerin demografik profilini anlamayı, 
Antalya'yı medikal tedavi için seçerken hangi kaynaklardan bilgi aldıklarını ve Antalya'da hangi medikal tedavilerden yararlandıkları gibi bilgileri öğrenmeyi amaçlamaktadır. Bu amaca yönelik olarak oluşturulan sorular sayesinde medikal turistlerin daha iyi anlaşılması ve medikal turistlere hizmet veren kurumların bu konulara dikkat göstermesinin sağlanması beklenmektedir.

\section{LİTERATÜR}

\subsection{Türkiye'de Sağlık ve Medikal Hizmet}

Yabancı hastaların son yıllarda seyahat etmesinin kolaylaşması, çoğu ülke için vize anlaşmalarının kalkması, sağlık hizmeti veren kurum ve kuruluşlara internet üzerinden hızlıca ulaşılması, Türkiye dâhil dünyada sağıık turizmi hareketliliğini arttırmıştır (ANSAT, 2014). Ek olarak Türkiye'nin 4 saatlik uçuş mesafesinde yaklaşık 1 milyar insana ve 57 ülkeye hitap eden avantajlı konumu turizm sektörü kadar medikal turizm dalında da ön plana çıkmasını sağlamıştır. Ülkeyi medikal turizmde ön plana çıkaran özellikler, uzman hekim kadrosu, nitelikli insan kaynağı, coğrafi yapısı, mevsimsel avantajları, kaliteli sağık hizmetleri, medikal teknolojileri, uygun tedavi maliyetleri, JCI belgeli hastane sayısı ve termal kaynakları olarak sıralanabilmektedir. Türkiye bu özellikler sayesinde her yıl binlerce medikal turiste hizmet vermektedir. Örneğin; Türkiye'de 2019 yılında sağlık turizmi ve turistin sağlığı kapsamında 662087 sağlık turisti hizmet almıştır. 2020 yılında yaşanan pandemi nedeniyle sayı azalarak 388150 medikal turiste düşmüştür. 2021 yılının ilk çeyreğinde ise 110716 medikal turist Türkiye de sağlık hizmeti almıştır (USHAŞ, 2021).

Medikal turistler tarafından en çok tercih edilen işlemlerin saç ekimi, kanser tedavileri, diş tedavileri ve fertililty (kısırık tedavileri) olduğu belirlenmiştir (Wecure, 2021). Medikal turistler tarafından tercih edilen tedavi çeşitlerinin yanı sıra, Türkiye'deki birçok hastane de onkolojik tedaviler, kardiyovasküler cerrahi, ortopedi, beyin cerrahisi, çocuk cerrahisi, estetik cerrahisi, göz ve dişte ileri teknolojili sağlık hizmetleri verilebilmektedir. Ek olarak bu hastanelerde Cyberknife, robotik cerrahi, MR hizmetleri, kemik iliği, organ transplantasyonu da yapılabilmektedir (Türkiye Sağlık Turizmi Derneği, 2016). Türkiye bu farklı medikal branşları ve gelişmiş teknolojili medikal hizmetleri için gelen medikal turistler sayesinde 2020 yılında 548 milyon 882 bin dolar, 2021 yılının ilk çeyreğinde ise 196 milyon 734 bin dolar gelir elde etmiştir (USHAŞ, 2021).

Kültür ve Turizm Bakanlığı, Türkiye'nin uluslararası alanda hizmet veren sağlık turizmi merkezlerini İstanbul, Ankara, Bursa, Antalya, Adana, Mersin, Kayseri ve Edirne olarak açıklamıştır (Turizm Günlüğü, 2018). 2019 
yılında Türkiye'de sağlık hizmeti almak için en çok Irak, Azerbaycan ve Türkmenistan'dan, 2020 yılında ise Irak, Somali Federal Cumhuriyeti ve Suriye Arap Cumhuriyeti'nden sağlık turisti gelmiştir (TRT Haber, 2021).

\subsection{Antalya'da Sağlık ve Medikal Hizmet}

Antalya, sağlık turizmindeki sıralaması ve Türkiye'de bulunduğu konum nedeni ile oldukça avantajlı bir bölgededir. Antalya'nın 15 ilçesinde (Akseki, Alanya, Muratpaşa, Demre, Elmalı, Finike, Gazipaşa, Gündoğmuş, Kaş, Kemer, Kepez, Korkuteli, Kumluca, Manavgat, Serik) 17 devlet hastanesi ve 1 üniversite hastanesine (Antalya İl Sağlık Müdürlüğü, 2021) sahiptir. Ayrıca ilde sağlık turizmi yetki belgesi almaya hak kazanan 61 sağlık tesisi (özel hastane, ağız ve diş sağlığı merkezleri, kamu hastaneleri, tıp merkezleri vb.) bulunmaktadır. Bu tesislerin 2 tanesi JCI belgeli iken 3.sü de bu belgeyi alma yolundadır (ANSAT, 2014).

Hem kamu hem de özel sektörün sağlık alanında büyük yatırımlara imza attığı ilde, kamu yatırımları arasında, Antalya Eğitim ve Araştırma Hastanesi ve Akdeniz Üniversitesi Tıp Fakültesi Hastanesi öne çıkmaktadır. Her türlü tedavinin ve operasyonun yapılabildiği bu hastaneler, 5 yıldızlı oteli aratmayan görünümleriyle de sağlık turizmi açısından önemli bir potansiyel taşımaktadır. Özellikle Akdeniz Üniversitesi Tıp Fakültesi Hastanesi'nde yapılan ileri düzeyde organ nakli ameliyatlarında yakalanan başarı oranı herkesin dikkatini çekmektedir. Antalya'da, kamu sektörünün yanı sıra, özel sektörün gerçekleştirdiği çok sayıda başarılı hizmetler bulunmaktadır. Tıpkı kamuda olduğu gibi özel sektörde de, organ nakli ve kanser tedavisi alanında dünya çapında öne çıkan kuruluşlar ve eğitimli personelleriyle üst düzeyde hizmet veren sağlık kurulumları bulunmaktadır (Antalya İl Kültür ve Turizm Müdürlüğü, 2021).

Sağıı turizmi kapsamında, medikal turizm, yaşlı ve engelli turizmi alanlarında ön plana çıkan ilde, başta Balkanlar, Ortadoğu, Rusya, Batı Avrupa, Kuzey Afrika, Türk Cumhuriyetleri ve Arap ülkelerinden olmak üzere çok sayıda turist tedavi amaçlı gelmekte; ağırlıklı olarak göz, diş, organ ve kemik iliği nakli, cerrahi, nefroloji ve kadın doğum alanlarında tedavileri tercih etmektedir. Son yıllarda, özellikle Körfez ülkelerinden ziyaretçiler, saç ekimi ve plastik cerrahi gibi zorunlu olmayan tıbbi operasyonlar için de Antalya'yı ve Türkiye'yi tercih etmektedir (Antalya İl Kültür ve Turizm Müdürlüğü, 2021).

Sağlık potansiyelinin yanı sıra, doğal ve tarihi güzelliklerle bezeli olan Antalya, coğrafi konumu, dört mevsim ılıman iklimi ve ulaşım kolaylığıyla, özellikle düşük sezon döneminde hasta, yaşlı ve engellilerin konaklaması için elverişli koşullar sunan bir kent olarak öne çıkmaktadır. Bu doğrultuda 
il; kış turizmi, spor turizmi, kongre ve fuar turizmi gibi alternatif turizm türlerinde olduğu gibi, sağlık turizminde de oldukça önemli bir yere sahiptir. Özellikle son yıllarda; yüksek yatak ve hizmet kapasiteli konaklama tesislerinin yanı sıra, gelişmiş altyapı ve donanıma sahip sağlık kuruluşları, alanında iyi yetişmiş, yabancı dil bilen uzman doktor ve sağlık personeli ve nitelikli, aynı zamanda diğer ülkelere kıyasla daha az maliyetli hizmet anlayışıyla Antalya'da, sağılı turizmi alanında önemli bir mesafe kat edilmiştir (Antalya İl Kültür ve Turizm Müdürlüğü, 2021).

\section{YÖNTEM}

Çalışma Antalya destinasyonunu medikal tedavi için tercih eden yabancı medikal turistlerin bazı tercihlerini ve demografik özelliklerini anlamak için yapılmıştır. Bu amaçla Antalya destinasyonuna gelen medikal turistler evren, Antalya'da daha önce medikal tedavi hizmeti almış olan veya çalışmanın yapıldığı dönemde medikal tedavi hizmeti almaya gelmiş olan medikal turistler ise örneklem olarak alınmıştır. Örneklem kapsamında 100 medikal turiste ulaşılmıştır. Örneklem sayısı az olarak görülse de örneklem sayısının belirlenmesinde en çok kullanılan yaklaşım araştırmadaki her bir soruya karşılık olarak 5, 10 ya da 20 gözlemin toplanması kuralıdır (İSTMER, 2021; Çokluk, Şekercioğlu ve Büyüköztürk, 2012; Aksu, Eser ve Güzeller, 2017; Tavşancıl, 2018). Araştırmada demografik değişkenler dahil katılımcılara 10 soru sorulduğu göz önüne alındığında örneklem sayısı yeterli olarak kabul edilebilmektedir. Diğer taraftan TUİK (2020) tarafından açıklanan verilere göre araştırma verilerinin toplandığı 2020 yılının son çeyreğinde (2.10.2020 - 22.12.2020) Türkiye'ye 144828 medikal turist (yabancı ve yurtdışında ikamet eden vatandaşlar) sağlık ve tıbbi nedenlerle gelmiştir. Bu rakamlardan 125 449'unu ise sadece yabancı uyruklu (yurtdışında ikamet edip Türkiye vatandaşı olmayan) medikal turistler oluşturmaktadır. Araştırma için kullanılacak olan rakam 125449 medikal turisttir. Çünkü, araştırmanın kısıtlarında katılımcıların yabancı uyruklu olması zorunluluğu vardı. Buna göre de Türkiye genelinde \%95 güven aralığında örneklem sayısı 383 olarak hesaplanmaktadır (Etik Araştırma, 2016). Araştırmanın yapıldığı dönemde Türkiye geneli 383 olan örneklem sayının Antalya iline indirgendiğinde daha az olması beklenen bir durumdur.

Araştırma kapsamında medikal turistlere cinsiyet, yaş, eğitim, uyruk, aylık, gelir gibi değişkenlerin haricinde aşağıdaki sorular yönlendirilmiştir:

- Türkiye'yi daha önce kaç kez ziyaret ettiniz?

- Antalya'yı daha önce kaç kez ziyaret ettiniz?

- Şu an gelişinizdeki temel amacınız nedir?

- Antalya'da aldığınız medikal tedavi nedir? 
- Antalya'yı tercih etmeden önce hangi kaynaklardan bilgi topladınız?

Araştırmacılara sorulacak soruların sorulmasında Hwang, Lee ve Kang (2018) ve Shahijan, Rezaei, Preece ve İsmail (2015)'in çalışmalarından yararlanılmıştır. Sorular ve anket formu medikal turistlere sadece İngilizce dilinde uygulanmıştır. Araştırmaya katılacak medikal turistlere ise hastane dışında, kaldıkları tesiste (otel, pansiyon vb.), çarşıda ya da sahilde ulaşılmıştır. Örnekleme dahil edilecek medikal turistler seçilirken bazı kriterler de belirlenmiştir. Bunlar:

- Antalya ilinde en az bir kere medikal tedavi hizmeti almış olması,

- Yabancı uyruklu olması,

- 18 yaşından büyük olması,

- Türkiye'de ikamet etmemesi.

Yukarıdaki kriterleri sağlayan medikal turistlere anket formu verilerek soruları cevaplaması istenmiştir. Anketlerin cevaplanmasın da ve toplanmasında yüz yüze anket tekniği kullanılmıştır. Bu kapsamda 2.10.2020 - 22.12.2020 tarihleri arasında 100 medikal turiste ulaşılmıştır. Ulaşılan turistlerden elde edilen sonuçlar betimsel istatistik ile analiz edilmiştir.

\section{VERI ANALİZi}

\subsection{Ankete Katılan Medikal Turistlerin Profili}

Şekil 1 (a) çalışma grubunun \%51,5'inin erkek, \%47,5'inin kadınlardan oluştuğunu göstermektedir. Kadın ve erkek medikal turist sayılarının birbirine çok yakın olduğu görülmektedir. Dolayısıyla hem erkek hem de kadınların medikal turizm profili ve görüşlerinden eşit oranda bilgi edinme olasılığı yüksektir.

Şekil 1 (b) yaş gruplarını göstermektedir. \%38,6'sı 43-50 yaşında, $\% 36,6$ 'sı 34-42 yaşında, \%14,9'u 36-33 yaşında, \%7,9'u 51 ve üzeri yaştayken sadece \%1'lik bir kısmı 18-25 yaş aralığında bulunmuştur.

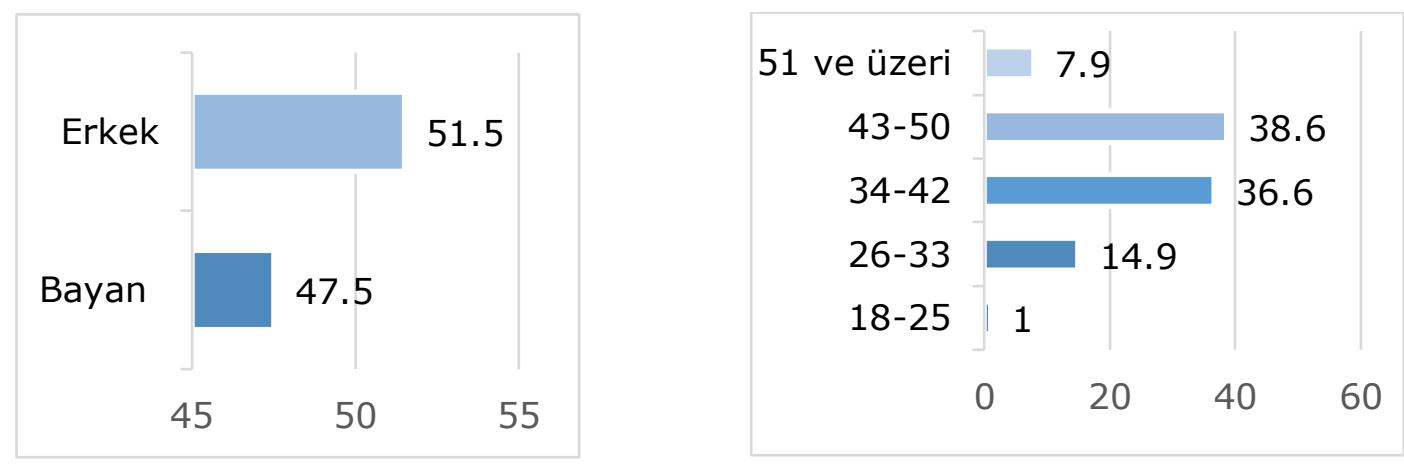

(b) Cinsiyet

(a) Yaş 
Şekil 1: Medikal Turistlerin (a) Cinsiyet ve (b) Yaş Dağılımları

Şekil 2 (a) örneklemin etnik kökenlerini göstermektedir. Buna göre \%21,8 Alman, \%7,9 Azeri, \%3 Bulgar ve Rumen, \%10,9 Hollanda, \%13,9 Irak, \%15,8 İran, \%2 Kazak ve Norveç, \%5,9 Libya, \%9,9 Rus ve \% 1 Arap, Belçika ve Fransa vatandaşlarından oluşmaktadır. Bu sonuçlar çeşitli etnik kökenli medikal turistlerin Antalya'ya geldiğini göstermektedir.

Şekil 2 (b) eğitim seviyelerini gruplandırmaktadır. \%8,9 lise, \%43,6 2 ya da 4 yıllık üniversite, \%38,6 master ve \%7,9 doktora eğitimlerine sahiptir. Sonuçlar incelendiğinde örneklemin iyi bir eğitim seviyesine sahip olduğu görülmektedir.

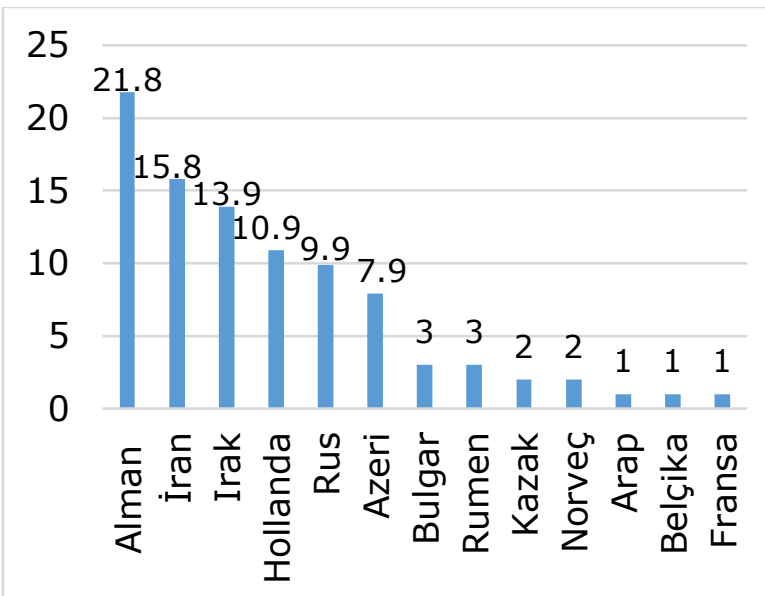

(a) Milliyet

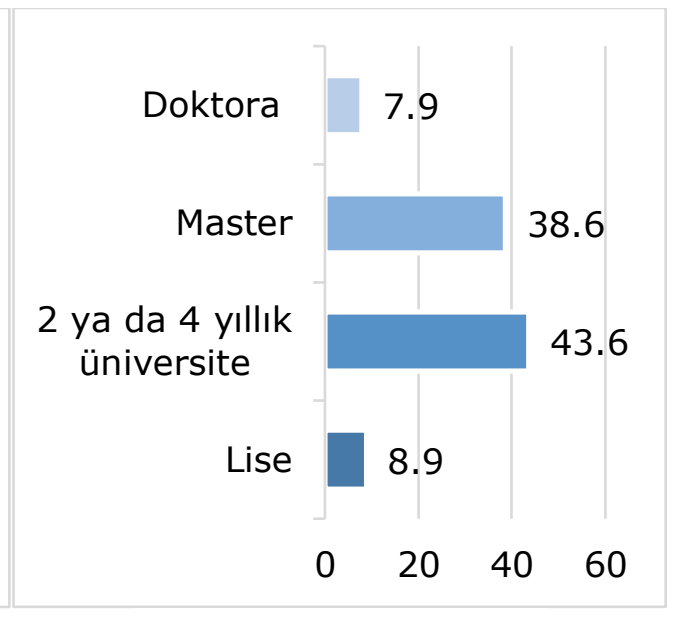

(b) Eğitim seviyeleri

Şekil 2: Medikal Turistlerin (a) Milliyet ve (b) Eğitim seviyeleri

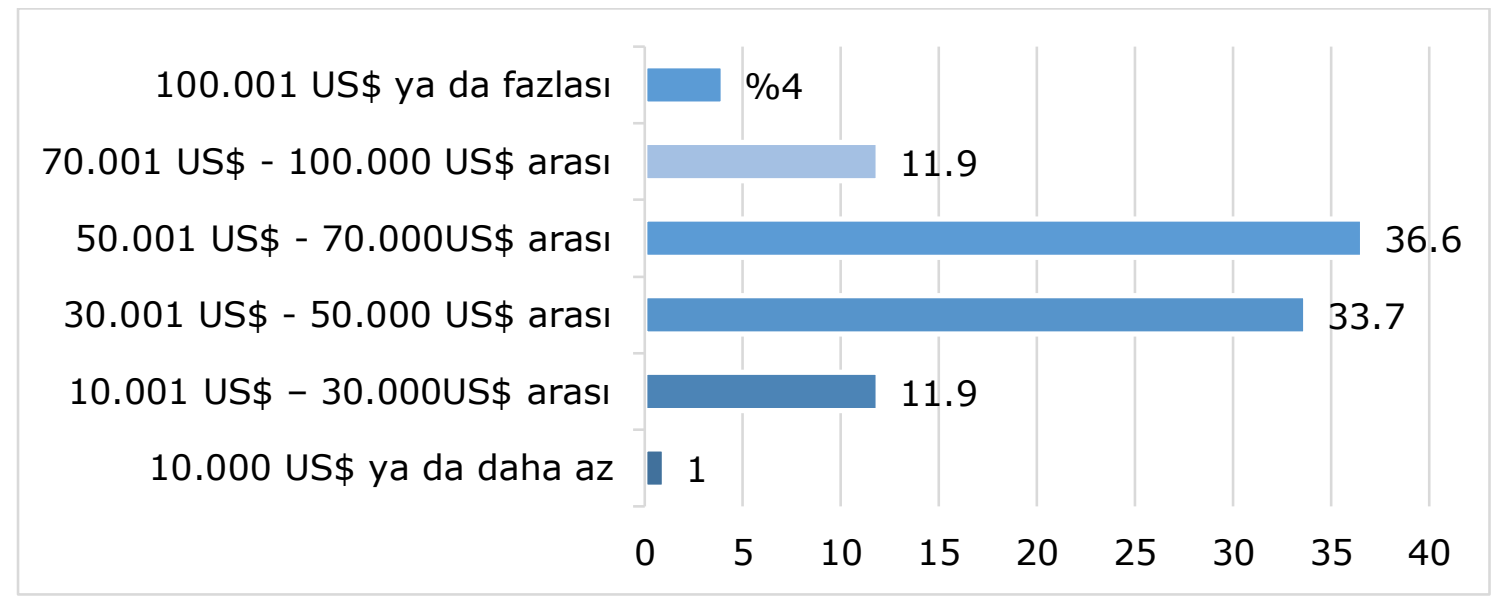

Şekil 3: Medikal Turistlerin Gelir Seviyeleri

Şekil 3'te gelir seviyeleri sıralanmıştır. Buna göre, \%1'i 10.000 US\$ ve daha az, \%11,9'u 10.001 US\$ - 30.000US\$ arası, \%33,7'si 30.001 US\$ to 50.000 US $\$$ arası, $\% 36,6$ 'sı 50.001 US $\$$ to 70.000 US $\$$ arası, $\% 11,9^{\prime}$ u 70.001 US $\$$ to 100.000 US\$ arası ve son olarak \%4'ünün 100.000 US\$ ve fazlası seviyesinde gelire sahiptir. 


\subsection{Ankete Katılan Medikal Turistlerin Daha Önceki Ziyaret Sayıları ve Ziyaret Amaçları}

Evren grubu Antalya'ya gelen medikal turistler olarak belirlenmişti. Örneklem ise, Antalya'da daha önce medikal tedavi hizmeti almış olan veya çalışmanın yapıldığı dönemde medikal tedavi hizmeti almaya gelmiş olan medikal turistler ise olarak alınmıştır. Daha önce medikal hizmet almış olan medikal turistlerin gruba dahil edilmesi örneklemi genişletmek ve kolaylaştırmak için yapılmıştır. Bu nedenle anketin uygulandığı dönemde turistler tatil için de gelmiş olsalar, daha önceden medikal hizmet almış olanlar örnekleme dâhil edilmiştir.

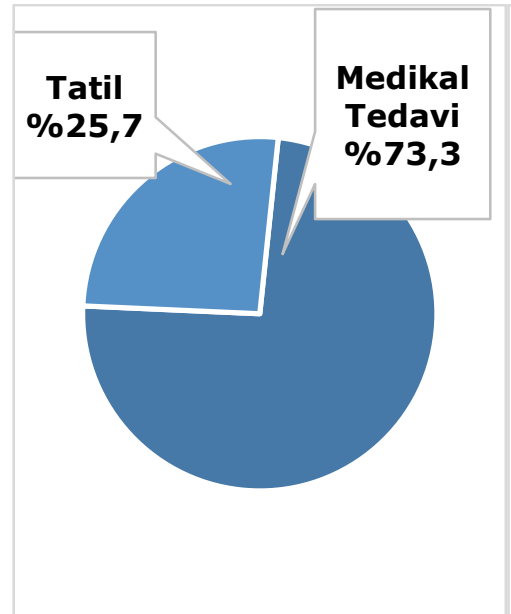

(a)

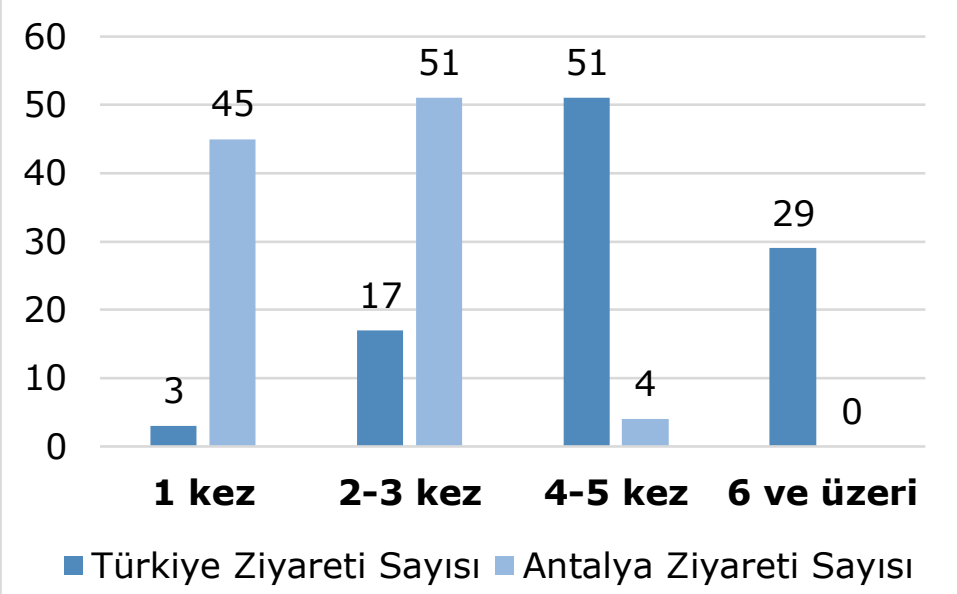

(b)

Şekil 4: (a) Ankete Katılan Medikal Turistlerin Antalya'yı Ziyaret Amaçları; (b) Ankete Katılan Medikal Turistlerin Türkiye ve Antalya'yı Ziyaret Sayıları

Şekil 4 (a)'da medikal turistlerin su anki geliş amaçları yer alırken, Şekil 4(b)'de ise daha önceki Antalya ve Türkiye ziyaretleri sayıları sunulmaktadır. Veriler her 10 kişiden 7'sinin medikal tedavi almak $(\% 73,3)$ amacıyla geldiğini göstermektedir. Gelen medikal turistlerin \%51'i daha önce Türkiye'yi 4-5 kez, Antalya'yı ise 2-3 kez ziyaret etmiştir. Örnekleme dâhil edilen her 10 kişiden 5'i Antalya ve Türkiye için deneyim sahibi olarak görülmektedir.

\subsection{Anket katılan medikal turistlerin gelmeden önce bilgi aldıkları kaynaklar}

Şekil 5 örneklem grubunun Antalya'ya medikal tedavi için gelmeden önce bilgi aldığı kaynakları göstermektedir. Sosyal ağlar (facebook, instagram vb.), forumlar, bloglar ve tıbbi topluluklar, medikal turizm fuarları, medikal turizmle uğraşan seyahat acentaları bilgi kaynakları olarak hiç işaretlenmemiştir. TV, gazete gibi kitle iletişim araçları \%3, medikal turizm broşürleri ise $\% 2^{\prime} l i k$ bir dilime sahiptir. 


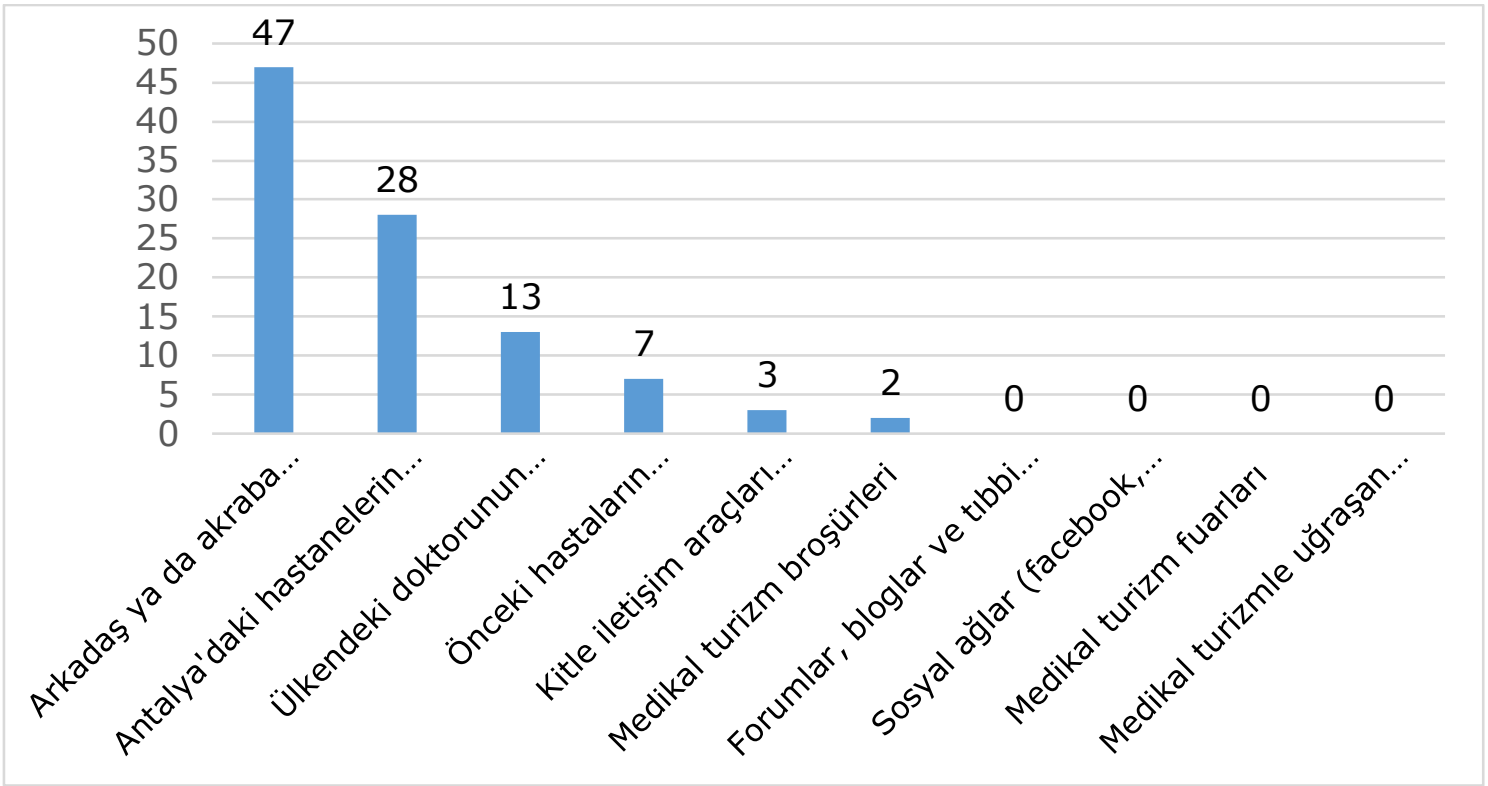

Şekil 5: Ankete Katılan Medikal Turistlerin Antalya'ya Gelmeden Önce Bilgi Aldıkları Kaynaklar

Şekil 5'te çoğunluğun yani \%47'lik bir dilimin bu konuda arkadaş ve akraba tavsiyelerine önem verdiği görülmektedir. Bunun nedeni teknolojiyle geç tanışan bir nesil olan 43-50 yaş grubunun fazla olması olabilir. Akraba tavsiyelerini \%28'lik bir dilimle Antalya'daki hastanelerin web sitelerinin incelenmesi, \%13'le geldikleri ülkedeki doktorun tavsiyesi ve \%7 ile de daha önce medikal hizmet alan hastaların forumlardaki yorumları takip etmektedir.

\section{4 Ankete katılan medikal turistlerin aldıkları tedavi çeşitleri}

Ankete katılım sağlayan medikal turistlerden hangi medikal tedavi hizmetini aldıklarını işaretlemeleri istenmiştir. 8 seçenekli tedavi çeşitlerinden hastalık teşhisi (\%1) için gelen sadece 1 kişi, estetik/plastik cerrahi (\%3) 3 kişi, kısırlık/çocuk tedavileri (\%2), check up (\%2) ve daha önceki alınan tedaviyi takip eden kontrol muayenesi (\%2) için gelen sadece 2 şer kişi bulunmaktadır. Örneklem kapsamında ulaşılan medikal turistlerin en çok aldıkları hizmet diş $(\% 44,6)$ ve göz tedavileri $(\% 32,7)$ olarak görülmektedir. Diğer seçeneğini işaretleyen $\% 11,9^{\prime}$ luk kesim ise saç ekimi tedavisi aldığını belirtmiştir. 


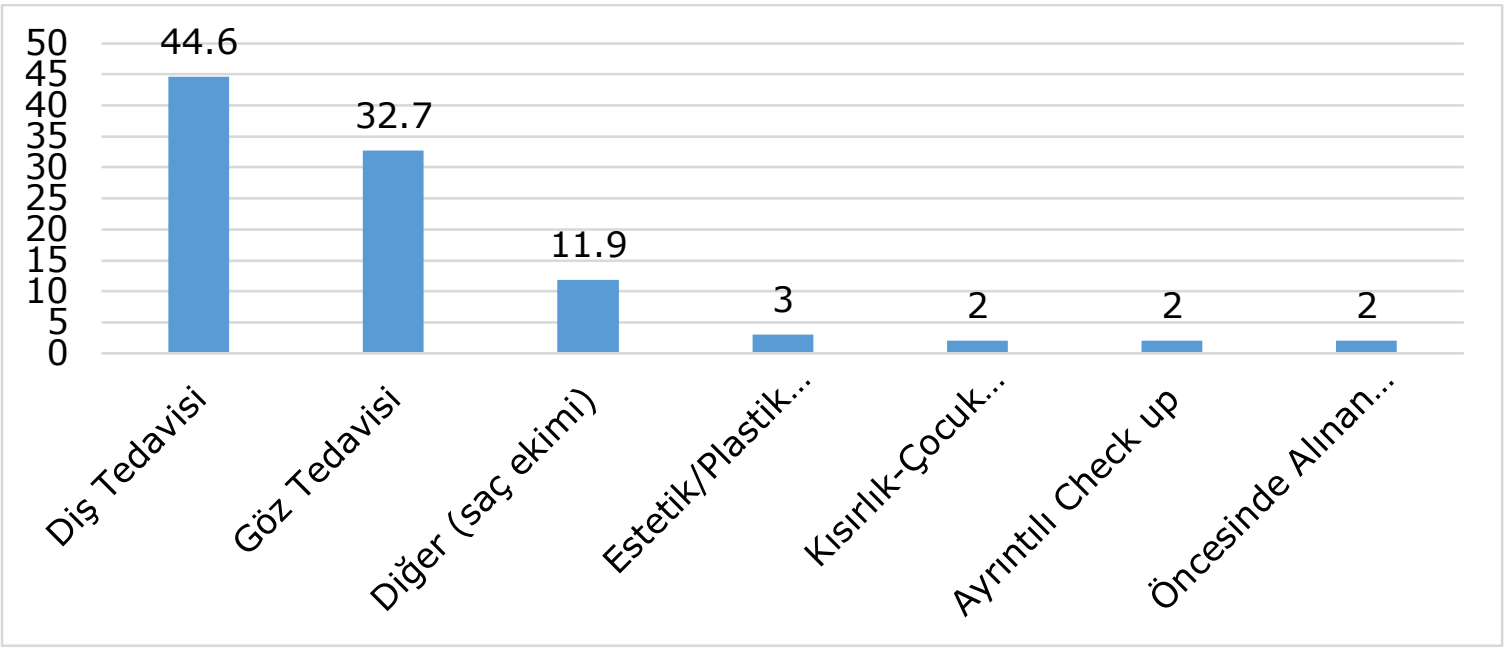

Şekil 6: Ankete Katılan Medikal Turistlerin Aldıkları Medikal Tedaviler

Şekil 6'da da görüldüğü gibi katılımcıların yaklaşık olarak \%75'inin göz ve diş tedavilerinden faydalandığı görülmektedir. \%12'ye yakın bir dilim ise saç ekimi hizmeti almıştır. Buna göre katılımcılardan her 2 kişiden biri diş tedavisi, her 3 kişiden biri göz tedavisi ve yaklaşık her 11 kişiden biri de saç ekim hizmeti almıştır.

\section{SONUÇ ve ÖNERİLER}

Önemli bir turizm çeşidi olarak popüler olan medikal turizm, Türkiye Sayfa | 1580 için öncelikli kazanç alanları arasında yer almaktadır. Yapılan çalışmada, Türkiye'de medikal turizm konusunda öncü sayılabilecek Antalya ilinin medikal turist profilini anlamak, Antalya'yı medikal tedavi için seçen medikal turistlerin hangi kaynaklardan bilgi aldıklarını ve Antalya'da hangi medikal tedavilerden yararlandıklarını öğrenmek amaçlanmaktadır. Çalışmanın amacına uygun olarak hazırlanan anket soruları Antalya'da en az bir kere medikal tedavi hizmeti almış olan medikal turistlere uygulanmıştır.

Yaş, gelir düzeyi ve eğitim seviyesi gibi sosyo-demografik özelliklerin medikal hizmetler için belirli bir ülkeye yapılacak seyahat kararını etkilediği bilinmektedir (Altın vd., 2011). Çalışma sonunda elde dilen verilere göre, Antalya'da medikal hizmet almaya çoğunlukla erkeklerin $(\% 51,5)$ geldiği, 34-50 yaş aralığındaki (\%38,6'sı 43-50 yaş grubu; \%36,6'sı 34-42 yaş grubu) grubun çoğunlukta olduğu, eğitim düzeyinin ( $\% 43,62$ ya da 4 yıllık üniversite; \%38,6 master) üniversite ve master seviyesinde olduğu ve gelir düzeyinin de (\%36,6'sı 50.001 US\$ - 70.000US\$ arası) yüksek denilebilecek seviyede olduğu görülmektedir. Yeni deneyimlere açıklık, gidilecek destinasyonun kültür ve diline olan aşinalık gibi kişisel faktörlerinde destinasyonla ilgili karar vermede destekleyici faktörler olduğu açıklanmaktadır (Altın vd., 2011). Bu kapsamda daha önceki ziyaret deneyimleri medikal turistlere bir aşinalık yaratmaktadır. Araştırmaya 
katılan medikal turistlerin \%51'inin Türkiye'yi daha önce 4-5 kez, Antalya'yı ise 2-3 kez ziyaret etmesinin destinasyon seçim kararlarını kolaylaştırdığı düşünülmektedir. Geçmişte, gelişmekte olan ülkelerden varlıklı kişiler kaliteli tıbbi bakım almak için gelişmiş ülkelere seyahat etmekteydi. Ancak şu anda, gelişmiş ülkelerden bireyler gelişmekte olan ülkelere giderek medikal bakım almak için seyahat etmektedir. Çalışma sonuçları da gelişmekte olan ülkeler arasında yer alan (Hallem ve Barth, 2011; Veerasoontorn vd., 2011) Türkiye'nin Antalya ilçesine en çok Almanya $(\% 21,8)$ gibi gelişmiş bir ülkeden medikal turistin geldiği görülmüştür. Sağlık turizmi içinde, medikal turizm, yaşı ve engelli turizmi alanlarında ön plana çıkan Antalya'da, ağırlıklı olarak göz, diş, organ ve kemik iliği nakli, cerrahi, nefroloji ve kadın doğum alanlarında tedaviler tercih edilmektedir (Antalya İl Kültür ve Turizm Müdürlüğü, 2021). Araştırma sonuçları da diş $(\% 44,6)$ ve göz $(\% 32,7)$ tedavilerine yoğun ilgi gösterildiğini doğrulamaktadır. Diğer sonuçlar kapsamında araştırmaya katılan medikal turistlerin \%73,3'ünün medikal hizmet için geldiği, medikal tedavi alacakları destinasyonu belirlemeden önce akraba ve arkadaş tavsiyelerini (\%47) dikkate aldıkları ve Antalya'daki hastanelerin web sitelerinden (\%28) bilgi edindikleri belirlenmiştir.

$\mathrm{Bu}$ çalışma temel olarak, Antalya'ya gelen medikal turistlerin Sayfa | 1581 demografik çerçevesini çıkarmaya, aldıkları medikal tedavi türlerini anlamaya ve gelmeden önce bilgi edindikleri kaynakları öğrenmeye odaklanmıştır. Bu amaçla da Antalya'yı tercih eden medikal turistlerin bazı tercih ve özelliklerine dair çeşitli faktörler araştırılmıştır: yaş, cinsiyet, eğitim, gelir, ziyaret sayıları, bilgi kaynakları ve tedavi çeşitleri gibi. Bu ifadelerden ve sorulardan elde edilen sonuçlar, Antalya'ya gelen medikal turistlerin daha iyi anlaşılmasını sağlayarak buna yönelik gelişimler yapılmasını sağlayacaktır. Ancak çalışma yorumlanmadan önce bazı sınırlamalara dikkat edilmesi ve gelecekteki çalışmalarında bu sınırlamaları dikkate alması gerekmektedir. İlk olarak çalışma küçük örneklem büyüklüğüne sahiptir. Gelecekteki çalışmalar katılımcı sayısını artırarak daha büyük örneklemle araştırmayı test etmelidir. İkinci olarak bu çalışma Antalya'ya gelen ve araştırma kapsamında ulaşılabilen medikal turistlerden elde edilen verilerle sınırlıdır. Gelecekteki çalışmalar genelleme amacıyla diğer şehirlerdeki medikal turistlerinde cevaplarını araştırmalıdır. Son olarak medikal turistlerin tedavilerinin çeşitlendirilmesi ve demografik özelliklerinin genişletilmesi gelecek çalışmalara farklı sonuçlarla yeni bulgular kazandırılmasını sağlayacaktır. 


\section{KAYNAKÇA}

Antalya Homes. (2021). Türkiye'de Sağlık Turizmi. Erişim Adresi: https://www.antalyahomes.com.tr/turkiyede-saglik-turizmi Erişim Tarihi: 04.09.2021.

Aksu, G., Eser, M. T. \& Güzeller, C. O. (2017). Açımlayıcı ve Doğrulayıcı Faktör Analizi ile Yapısal Eşitlik Modeli Uygulamaları. Ankara: Detay Yayıncilık.

Altin, M., Singal, M., \& Kara, D. (2011). Consumer Decision Components for Medical Tourism: A Stakeholder Approach. In 16th Graduate Student Research Conference in Hospitality and Tourism, January 2011. Houston.

ANSAT. (2014). Antalya Sağlık Turizmi Derneği. Erişim Adresi: https://ansat.org.tr/index/ Erişim Tarihi: 14.06.2021.

Antalya İl Kültür ve Turizm Müdürlüğü. (2021). Sağlık Turizmi, Erişim Adresi: https://antalya.ktb.gov.tr/TR-175451/saglik-turizmi.html, Erişim Tarihi: 14.06.2021.

Antalya İl Sağlık Müdürlüğü. (2021). Erişim Adresi: https://www.antalyasm.gov.tr/kamu-hastaneler/tum-kamu-hastaneler, Erişim Tarihi: 14.06.2021.

Çokluk, Ö., Şekercioğlu, G., \& Büyüköztürk, Ş. (2012). Sosyal Bilimler İçin Çok Değişkenli İstatistik SPSS ve LISREL Uygulamaları. Ankara: Pegem Akademi.

Etik Araştırma. (2016). Bilgi Merkezi. Erişim Adresi: http://etikarastirma.com/tr/icerik/bilgi-merkezi/10 Erişim Tarihi: 05.09.2021.

Hadi, A. (2009, November). Globalization, Medical Tourism and Health Equity. In Symposium on Implications of Medical Tourism for Canadian Health and Health Policy 13, 1-29.

Hallem, Y. \& Barth, I. (2011). Customer-Perceived Value of Medical Tourism: An Exploratory Study - The Case of Cosmetic Surgery in Tunisia. Journal of Hospitality and Tourism Management 18, 121-129.

Herrick, D. (2007). Medical Tourism: Global Competition in Healthcare. National Centre for Policy Analysis (No. 304). Erişim Adresi: http://w.medretreat.com/templates/UserFiles/Documents/ MedicalTourism-NCPA Report.pdf.

Hwang, S., Lee, D. \& Kang, C. Y. (2018). Medical Tourism: Focusing on Patients' Prior, Current, and Post Experience. International Journal of Quality Innovation 4(1), 1-22. 
İSTMER. (2021). Örneklem Büyüklüğü Hesaplama Yaklaşımları ve 3 Alternatif Strateji. Erişim Adresi: https://www.istmer.com/orneklembuyuklugu-hesaplama-yaklasimlari/ Erişim Tarihi: 05.09.2021.

Kelley, E. (2013). Medical Tourism. In WHO Patient Safety Programme (pp. 1-23). Geneva: World Health Organization.

Lunt, N., Smith, R. D., Mannion, R., Green, S. T., Exworthy, M., Hanefeld, J., Horsfall, D., Machin, L. \& King, H. (2014). Implications for the NHS of Inward and Outward Medical Tourism: A Policy and Economic Analysis Using Literature Review and Mixed-Methods Approaches. Southampton: NIHR Journals Library.

Medical Tourism Association. (2014). Medical Tourism FAQ's. Erişim Adresi: http://www.medicaltourismassociation.com/en/medical-tourism-faqs.html Erişim Tarihi:18.04.2015.

Koggalage, P. D., Gunawardena, N. S. \& De Silva, A. H. (2017). Medical Travellers' Perspectives in Selecting in-Patient Services at Selected Private Hospitals in Sri Lanka. Asia Pacific Journal of Tourism Research 22(7), 747757.

Sağlık Bakanlığı, Sağlık Hizmetleri Genel Müdürlüğü. (2012). Sağlık Turizmi El Kitabı. Ankara: BMS Matbaacılık.

Shahijan, M. K., Rezaei, S., Preece, C. N. \& İsmail, W. K. W. (2015). International Medical Travelers' Behavioral Intention: An Empirical Study in Iran. Journal of Travel \& Tourism Marketing 32(5), 475-502.

Tavşancıl, E. (2018). Tutumların Ölçülmesi ve SPSS ile Veri Analizi. Ankara: Nobel Akademik Yayıncilık.

TRT Haber. (2021). Sağlık Turizminde Tercih Türkiye Oldu. Erişim Adresi: https://www.trthaber.com/haber/ekonomi/saglik-turizminde-tercihturkiye-oldu-564865.html Erişim Tarihi: 02.09.2021.

TUİK. (2021). İstatistiksel Tablolar. Erişim Adresi: https://data.tuik.gov.tr/Bulten/Index?p=Turizm-Istatistikleri-IV.Ceyrek:Ekim-Aralik-ve-Yillik,-2020-37438 Erişim Tarihi: 05.06.2021.

Turizm Günlüğü. (2018). Türkiyenin 8 Sağlık Turizm Merkezini Seçti. Erişim Adresi: https://www.turizmgunlugu.com/2021/05/05/kultur-veturizm-bakanligi-turkiye-saglik-turizm-merkezleri/ Erişim Tarihi: 02.09.2021.

Türkiye Sağlık Turizmi Derneği. (2016). Sağlık Turizmi Genel Bilgi. Erişim Adresi: http://www.saglikturizmi.org.tr/tr/saglikturizmi/genel-bilgi Erişim Tarihi: 01.06.2021. 
USHAŞ. (2021). Sağlık Turizmi Verileri. Erişim Adresi: https://www.ushas.com.tr/saglik-turizmi-verileri/ Erişim Tarihi: 14.6.2021. Veerasoontorn, R., Beise-Zee, R. \& Sivayathorn, A. (2011). Service Quality as a Key Driver of Medical Tourism: The Case of Bumrungrad International Hospital in Thailand. International Journal of Leisure and Tourism Marketing, 2(2), 140-158.

Wecure. (2021). Türkiye Sağlık Turizmi İçin Neden İdeal Bir Destinasyondur?. Erişim Adresi: https://wecure.co.uk/whyturkeyidealdestinationhealthtourism/\#: : text= Well\%2Drounded\%20when\%20it\%20comes\%20to\%20treatment\%20offer ings\&text=People\%20around\%20the\%20world\%20travel,smoking\%20an d\%20mental\%20health\%20therapy.,eri\%C5\%9Fim Erişim Tarihi: 17.03.2021.

GENIŞLETÍLMIş ÖZET: Medikal turizm, bireylerin kendi ülkelerinde var olana kıyasla daha kaliteli tıbbi, diş ve cerrahi hizmetlere ulaşabilmek adına başka bir ülkeye seyahat etmesi olarak tanımlanmaktadır. Geçmişte, gelişmekte olan ülkelerden varlıkı kişiler kaliteli tıbbi bakım almak için gelişmiş ülkelere seyahat ederken, yeni dönemde gelişmiş ülkelerden bireyler gelişmekte olan ülkelere giderek medikal bakım almak için seyahat etmektedir. Bu da gelişmekte olan ülkeleri medikal turizm için popüler destinasyonlar haline getirmektedir. Gerçekleşen dönüşüm kapsamında, günümüz lider medikal turizm destinasyonları arasında yer alan Türkiye incelenmesi gereken bir ülke olarak düşünülmüştür. Bunun için seçilen Antalya destinasyonu evren olarak alınmıştır. Antalya'nın seçilmesinde sağlık potansiyelinin yanı sıra, doğal ve tarihi güzelliklerle bezeli olması, coğrafi konumu, dört mevsim ılıman iklimi ve ulaşım kolaylığı gibi avantajları etkili olmuştur. Bunlara ek olarak il; kış turizmi, spor turizmi, kongre ve fuar turizmi gibi alternatif turizm türlerinde olduğu gibi, sağlık turizminde de oldukça önemli bir yere sahiptir. Özellikle son yıllarda; yüksek yatak ve hizmet kapasiteli konaklama tesislerinin yanı sıra, gelişmiş altyapı ve donanıma sahip sağlık kuruluşları, alanında iyi yetişmiş, yabancı dil bilen uzman doktor ve sağlık personeli ve nitelikli, aynı zamanda diğer ülkelere kıyasla daha az maliyetli hizmet anlayışıyla Antalya'da, sağlık turizmi alanında önemli bir mesafe kat edilmiştir. Bu doğrultuda Antalya'da medikal tedavi hizmeti almış olan medikal turistlerin demografik profilini anlamak, medikal turistlerin Antalya'yı medikal tedavi için seçerken hangi kaynaklardan bilgi aldıklarını ve Antalya'da hangi medikal tedavilerden yararlandıklarını öğrenmek için araştırma gerçekleştirilmiştir. Bu amaçla Antalya medikal turist profiline dair çeşitli faktörler araştırımıştır: yaş, cinsiyet, eğitim, gelir, ziyaret sayıları, bilgi kaynakları ve tedavi çeşitleri gibi. Bu kapsamda Antalya'daki medikal turistler örneklem olarak alınmıştır. Daha önce Antalya'da medikal tedavi hizmeti almış olan veya anketin yapıldığı dönemde medikal tedavi almak için gelmiş olan medikal turistler çalışmaya dâhil edilmiştir. Medikal turistlere tedavi aldıkları medikal tesiste ya da konaklama tesisinde ulaşılmıştır. Çalışma Antalya merkezde yürütülmüştür. Çalışma sonunda elde 
edilen verilere göre, Antalya'da medikal hizmet almaya çoğunlukla erkeklerin (\%51,5) geldiği, 34-50 yaş aralığındaki (\%38,6'sı 43-50 yaş grubu; \%36,6'sı 3442 yaş grubu) grubun çoğunlukta olduğu, eğitim düzeyinin ( $\% 43,62$ ya da 4 yıllık üniversite; \%38,6 master) üniversite ve master seviyesinde olduğu ve gelir düzeyinin de (\%36,6'sı 50.001 US\$ - 70.000US\$ arası) yüksek denilebilecek seviyede olduğu görülmektedir. Araştırmaya katılan medikal turistlerin \%51'inin Türkiye'yi daha önce 4-5 kez, Antalya'yı ise 2-3 kez ziyaret etmesinin destinasyon seçim kararlarını kolaylaştırdığı düşünülmektedir. Ayrıca gelişmekte olan ülkeler arasında yer alan Türkiye'nin Antalya ilçesine en çok Almanya $(\% 21,8)$ gibi gelişmiş bir ülkeden medikal turistin geldiği görülmüştür. Diğer sonuçlar kapsamında araştırmaya katılan medikal turistlerin \%73,3'ünün medikal hizmet için geldiği, diş $(\% 44,6)$ ve göz $(\% 32,7)$ tedavilerine yoğun ilgi gösterdikleri, medikal tedavi alacakları destinasyonu belirlemeden önce akraba ve arkadaş tavsiyelerini (\%47) dikkate aldıkları ve Antalya'daki hastanelerin web sitelerinden (\%28) bilgi edindikleri belirlenmiştir.

EXTENDED ABSTRACT: Medical tourism is defined as individuals traveling to another country in order to reach higher quality medical, dental and surgical services compared to the ones available in their own country. In the past, wealthy people from developing countries traveled to developed countries to receive quality medical care, while in the new era, individuals from developed countries travel to developing countries to receive medical care. This makes developing countries popular destinations for medical tourism. Within the scope of the transformation that has taken place, Turkey, which is among the leading medical tourism destinations today, has been considered as a country to be examined. For this, the chosen Antalya destination was taken as the universe. In addition to its health potential, Antalya's advantages such as being adorned with natural and historical beauties, geographical location, mild climate in all seasons and ease of transportation were effective in choosing Antalya. In addition to these, the province; It has a very important place in health tourism as well as in alternative tourism types such as winter tourism, sports tourism, congress and fair tourism. Especially in recent years; In addition to accommodation facilities with high bed and service capacity, health institutions with advanced infrastructure and equipment, well-trained specialist doctors and health personnel who speak foreign languages, and qualified and at the same time less costly service approach in Antalya, in the field of health tourism significant progress has been made. In this direction, research has been carried out to understand the demographic profile of medical tourists who have received medical treatment in Antalya, to learn from which sources medical tourists get information when choosing Antalya for medical treatment, and which medical treatments they benefit from in Antalya. For this purpose, various factors related to Antalya medical tourist profile were investigated: age, gender, education, income, number of visits, information sources and types of treatment. In this context, medical tourists in Antalya were taken as a sample. Medical tourists who received medical treatment in Antalya before or who came to receive medical treatment at the time of the survey were 
included in the study. Medical tourists were reached at the medical facility or accommodation facility where they received treatment. The study was carried out in the center of Antalya. According to the data obtained at the end of the study, it was found that mostly men ( $51.5 \%)$ come to receive medical services in Antalya, in the $34-50$ age group (38.6\% in the $43-50$ age group; $36.6 \%$ in the $34-42$ age group). age group), the education level (43.6\% 2- or 4 -year university; $38.6 \%$ master) is at university and master level, and the income level (36.6\% is 50,001 US\$ - 70,000US\$). between) is seen to be at a high level. It is thought that $51 \%$ of the medical tourists participating in the research have visited Turkey 4-5 times and Antalya 2-3 times before, which facilitates their destination selection decisions. In addition, it has been observed that most of the medical tourists from a developed country such as Germany (21.8\%) come to Antalya district of Turkey, which is among the developing countries. Within the scope of other results, $73.3 \%$ of the medical tourists participating in the research came for medical service, showed great interest in dental $(44.6 \%)$ and eye $(32.7 \%)$ treatments, and gave recommendations of relatives and friends (\%) before determining the destination where they would receive medical treatment. 47) and they obtained information from the websites of the hospitals in Antalya (28\%). 